\title{
ADOPTION OF ISO 9000 MANAGEMENT STANDARD IN EU'S TRANSITION ECONOMIES: THE CASE OF THE BALTIC STATES
}

\author{
Iñaki Heras-Saizarbitoria ${ }^{1}$, Germán Arana ${ }^{2}$, Ernesto Cilleruelo ${ }^{3}$ \\ ${ }^{1}$ Department of Management, E.U.E. Empresariales, University of the Basque Country \\ UPV/EHU, Plaza Oñati 1, 20018 San Sebastian, Spain \\ ${ }^{2}$ Department of Management, E.U. Politécnica, University of the Basque Country UPV/EHU, \\ Plaza Europa 1, 20018 San Sebastian Spain \\ ${ }^{3}$ Department of Management, E.T.S. de Ingeniería, University of the Basque Country \\ UPV/EHU, Alameda de Urquijo s/n, 48013 Bilbao, Spain \\ E-mails: ${ }^{1}$ iheras@ehu.es (corresponding author); ${ }^{2}$ g.arana@ehu.es; ${ }^{3}$ ernesto.cilleruelo@ehu.es
}

Received 19 July 2011; accepted 17 October 2011

\begin{abstract}
This article analyzes the dissemination of the main global management standards, the ISO 9000, within the transition economies of the European Union (EU). In the article, the specific case of the Baltic States is analyzed in depth. The work refers to the diffusion of the ISO 9000 standard in the Baltic States in terms of its certification intensity and sectorial distribution. Likewise, the work refers to the huge increase of certifications achieved by the countries and the other transition economies in the previous years of their adhesion to the European Union in years 2004 and 2007. The conclusions drawn in the article may be of interest both for academic and professional spheres of activity but, overall, for public-decisors.
\end{abstract}

Keywords: international standards, standardization, harmonization, ISO 9000, transition economies, Baltic States.

Reference to this paper should be made as follows: Heras-Saizarbitoria, I.; Arana, G.; Cilleruelo, E. 2013. Adoption of ISO 9000 management standard in EU's transition economies: the case of the Baltic States, Journal of Business Economics and Management 14(3): 481-499.

JEL Classification: F00, L00, L15, M20.

\section{Introduction}

In the last two decades we have witnessed an acceleration of the process of harmonization with regard to business management, in an economic context characterized by a marked process of globalization and economic integration of markets. In a global economy, without standardization and its results - standards, technical standards and specifications - interchanges would become exceedingly difficult. Standardization can, then, stimulate international trade by eliminating obstacles arising from different na- 
tional practices. Thus, standards are important for the promotion of economic efficiency as they provide a basis for reducing information-related transaction costs (Nadvi and Wältring 2004).

Standardization, or harmonization, could be defined in a general way as an activity aiming to apply an ordered system to repetitive functions that take place in the context of industry, technology, science and the economy. Standardization constitutes a mechanism of coordination and an instrument of regulation comparable to other instruments such as public regulations, markets, and hierarchies or formal organizations (Antonelli 1994; Brunsson and Jacobsson 2000). Standardization has been crucial for the development of the industrial society (Blind 2004). At its origins, in the early 20th century, standardization was introduced in order to curb an uneconomical divergence of components, parts and supplies and to foster their interchangeability so as to facilitate mass production and the repair and maintenance of products and services. Standardization, however, has gone further than this and has come to be applied to the very management processes and systems by which products and services are produced (Heras 2006). Brunsson and Jacobsson (2000) refer to these as standards for administrative processes, and Furusten (2000) as "standards on how to design and manage organizations". We can explicitly identify these administrative standards with what we would define here as management system standards (MSS), also referred to as metastandards (Uzumeri 1997), two terms that already have a tradition of academic acceptance (e.g. Corbett and Yeung 2008).

These management standards are, of course, to be distinguished from the technical norms and specifications relating to those requirements with which particular products or processes need to comply. MSSs are standards which correspond to the standardization of a very wide range of aspects of business activity, such as quality management (e.g. ISO 9000), environmental management (e.g. ISO 14000), the prevention of occupational hazards and the provision of health and safety regulations in the workplace (e.g. OHSAS 18000), and corporate social responsibility (e.g. SA 8000, ISO 26000). All of these standards tend to have a very similar methodology in relation to their creation, structure, process of implementation and monitoring by a third party. Among them ISO 9000 is arguably the most influential single international MSSs that there has been to date (Braun 2005).

This article contains an analysis of the adoption of this main global management standard on an international level within the EU's transition economies. Furthermore, the article focuses on the specific case of the Baltic States, where the EU's importance in foreign trade has grown rapidly (Liuhto and Jumpponen 2003). Following this introduction, ISO 9000 is presented in short. In the third section a very short overview of the relationship between ISO 9000 and international business is presented. The fourth section contains an empirical analysis of the dissemination of ISO 9000 within the EU, and, in special, in its transition economies. The fifth section features a specific analysis of the dissemination of ISO 9000 within the Baltic States. The paper concludes with a summary of the main discussion and the conclusions drawn and references. 


\section{ISO 9000: the first global management standard}

The ISO 9000 family of standards was created, in its initial form, in 1987, and underwent substantial revisions in 1994 and $2000^{1}$, by the International Standardization Organization (the last version of the standard has been launched in 2008). This body, known by its acronym ISO ${ }^{2}$ and that was created in 1947 , is an entity made up by more than 100 member states, and its objective is to favour the development of standardization, thus facilitating the interchange of products and services between countries. It has to date published over 14,000 international standards (known as ISO standards), some of which are management standards.

It must be made clear that the ISO 9000 standards are not standards that refer to compliance with an objective or with a particular result, i.e., they are not performance standards that measure the quality of companies' products or services, but rather standards that establish the need to systematize and formalize a whole series of company processes into a series of procedures, and to document this implementation. ISO 9000 standardizes procedures, duties, and roles, rather than goals or outcomes (Braun 2005). It is because of this that such standards are often criticized in the field of management studies for their tendency to increase bureaucracy and excessive rigidity (cf., for example, Seddon 1997; Dick 2000).

In short, compliance with ISO 9000 - a fact which is certified by an organism accredited for this purpose - means having documentation to show the implementation of a quality management system which includes in standardized and documented procedures the basic processes used to produce the product or service which the customer acquires. These standards are a management tool based on the systematization and formalization of tasks in order to achieve product homogeneity and to conform to the specifications established by the customer (Anderson et al. 1999). In other words, as one manager summarized to Cole (1999), "document what you do, do what you document, and verify that you are doing it:"

Such a clarification is, in our opinion, especially pertinent, since there have been major misunderstandings in this respect on numerous occasions in the past, and in a variety of different fields. For example, in countries such as Spain and Italy - leaders in the world league table for ISO 9000 certification - numerous companies have publicized their certificate as a registered company as though it were a product quality label, despite the fact that the ISO standard itself prohibits such a practice (Heras 2006).

\footnotetext{
1 "ISO 9000 standards" or "the ISO 9000 family of standards" are the expressions commonly used to refer to the totality of standards in the same series, although in the 2000 version the only standard which includes a model for implementing a certifiable management system (i.e., the only management system standard) is the ISO 9001 standard. In fact, in the 1987 and 1994 versions, in addition to the ISO 9001 standard, the ISO 9002 and ISO 9003 standards also included certifiable management system models, which is why the plural form used previously continues to be employed. Loosely speaking, reference is still made to "ISO 9000" or "certified in accordance with ISO 9000", whereas, properly speaking, the correct expression should be "ISO 9001 standard" or "certified in accordance with ISO 9001" (there is an ISO 9000 standard in the current series, but it is a standard applied to definitions and terminology).

2 ISO was reconstituted as the successor organization to the short-lived International Standards Association which had already been established in the 1920s (Braun 2005).
} 
It should also be stated that the implementation of this type of standard or norm is voluntary, although in certain sectors their application constitutes a de facto obligation. In this way (and as will be examined subsequently below), in those studies in which an analysis has been made of companies' motivations for obtaining certification, considerable emphasis has been accorded to the "prescriptive" role played by large companies in the construction, automotive, energy and telecommunications sectors. The latter saw in the ISO 9000 standards a way of ensuring a certain level of quality from their suppliers and subcontractors, in the sense of obtaining a certain systematization and formalization of the key processes utilized by such companies to comply with the requirements that the larger companies had established, but without increasing their operational costs.

\section{ISO 9000 and International business}

From an international business perspective, the successful diffusion of ISO 9000 would appear to be closely linked to the basic impetus of the process of globalization of the Western economies, to the extending global supply chains and the still growing importance of multinational companies (MNCs) (Boiral 2001; Braun 2005). In the current economic environment, in which outsourcing and relocation of companies' activities have become key strategic elements of global supply chains, it is necessary to foster certain homogeneity of management systems in order to favour the development of such processes, and ISO 9000 may help to achieve this aim (Heras 2006), in order to reduce power asimmetries in global supply chains (Tapiero 2006). As stressed by Clougherty and Grajek (2008) for ISO 9000 MSSs provide a common language (i.e., common routine, shared experience, similar climate, etc.) that helps firms from different nations to consummate (i.e., successfully integrate) international acquisitions and joint-ventures.

Table 1. Macro-level drivers of ISO 9000: an empirical literature review

\begin{tabular}{|c|c|c|}
\hline & Countries & Contributions/Findings \\
\hline Corbett and Kirsch (2001) & 63 & ISO 9000 level depend on export-propensity \\
\hline Guler et al. (2002) & 71 & $\begin{array}{l}\text { Multinationals through inward FDI and the national } \\
\text { cohesive trade relationships }\end{array}$ \\
\hline Pan (2003) & $\begin{array}{l}4(\text { Far } \\
\text { eastern) }\end{array}$ & Strong link between ISO 9000 and ISO 14000 certification \\
\hline Grajek (2004) & 101 & $\begin{array}{l}\text { Positive effect of foreign customers' adoption on domestic } \\
\text { adoptions }\end{array}$ \\
\hline Neumayer and Perkins (2005) & 142 & Stock of FDI and exports to Europe and Japan \\
\hline Alburquerque et al. (2007) & 56 & Bilateral trade and geographical proximity for ISO 9000 \\
\hline Cao and Prakash (2007) & 164 & $\begin{array}{l}\text { Trade and foreign investment networks support ISO } 9000 \\
\text { diffusion }\end{array}$ \\
\hline Corbett (2008) & 9 & $\begin{array}{l}\text { Pressure exerted by downstream customers through global } \\
\text { supply chains }\end{array}$ \\
\hline Masakure et al. (2009) & $\begin{array}{l}1 \\
\text { (Pakistan) }\end{array}$ & $\begin{array}{l}\text { Export performance is positively correlated with ISO } 9000 \\
\text { certification }\end{array}$ \\
\hline Bodas-Freitas (2009) & $8(\mathrm{OECD})$ & Trade with UK and Germany fosters ISO 9000 certification \\
\hline
\end{tabular}

Source: Own preparation. 
In the specialised literature, it is pointed out that the main driving force behind firms becoming certified is mainly related to customer and market pressures (see for instance, Boiral 2001; Guler et al. 2002; Braun 2005; Shin 2005; Duanmu and Fai 2007; Guasch et al. 2007). In accordance with these contributions, ISO 9000 certification prove very important for entry into supply chains, supplier networks, and export consortia.

A set of studies stress that there exists a positive correlation between the number of certificates and macro-economic variables such as the volume of direct overseas investment, the tendency to export to the EU and the country's public expenditure (see Table 1). Research by Cao and Prakash (2007) concluded that the adoption of ISO 9000 in a given country is likely to be encouraged if its salient export markets have high levels of ISO 9000 adoptions. Alburquerque et al. (2007) pointed out that the diffusion of ISO 9000 is driven primarily by geography and bilateral trade relations.

\section{ISO 9000 dissemination within the transition economies of the EU}

By late 2009, over 1,060,000 ISO 9000 certificates had been authorized in a total of 175 countries all over the world (see Figure 1), thus more than doubling the number of certificates compared with the figure for the end of the year 2000, a year during which a new version of the standards was launched, and by the end of which there were a total of 457,834 such certificates (ISO 2010).

Continent by continent, it can be seen that the EU, with 407,155 certificates issued, continues to lead in terms of total number of ISO 9000 certificates, since it absorbs more than the third of the total number of certificates awarded throughout the world (more precisely, $38.24 \%$ of the total). Nevertheless, this global leadership has diminished by more than ten percentage points when compared with the year 2000. China is the country with the largest number of certificates in the world (having a total of 257,056 by the end of 2009), followed by Italy (with 130,066), Japan $(68,484)$, Spain $(59,576)$ and Russian Federation $(53,152)$.

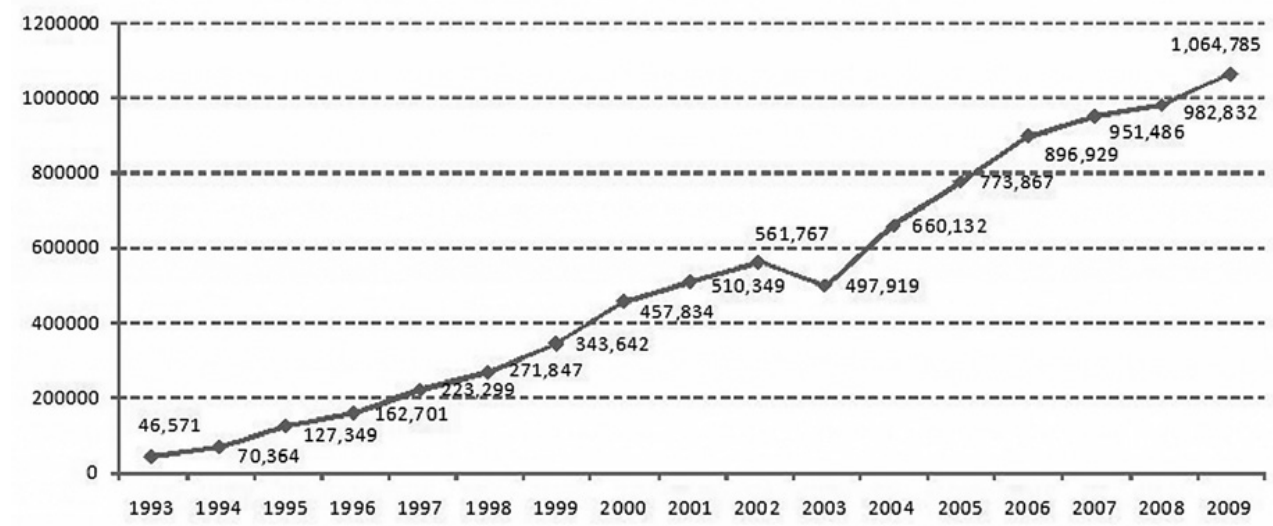

Fig. 1. Worldwide temporal diffussion of ISO 9000

Source: Own preparation on the basis of the various executive reports on the global statistics for ISO 9000 published by ISO. 
Ideally, the figures on ISO certifications should be weighted against the number of potential ISO certifiable enterprises in each country, and by industry structure of enterprises, in order to ascertain the degree of diffusion within the economy. As an approximation to that indicator we propose the Certification Intensity (CI). CI for the entire world, for instance (see Table 2), is calculated as a ratio between the percentage of participation in the number of global certificates issued and the percentage participation in the world GDP.

Table 2. International adoption of ISO 9000 in the main global economic zones

\begin{tabular}{llllllll}
\hline & \multirow{2}{*}{1997} & \multirow{2}{*}{2001} & 2005 & \multicolumn{3}{c}{2009} \\
\cline { 5 - 7 } & & & & $\mathrm{N}$ & $\%$ & CI \\
\hline USA & 18,581 & 37,026 & 44,270 & 28,935 & 2.72 & 0.24 \\
\hline Japan & 6,487 & 27,385 & 53,771 & 68,484 & 6.43 & 1.37 \\
\hline European Union & 135,984 & 253,488 & 344,672 & 407,155 & 38.24 & 1.58 \\
\hline China & 5,698 & 57,783 & 143,823 & 257,056 & 24.14 & 1.72 \\
\hline World & 223,219 & 510,616 & 773,867 & $1,064,785$ & 100.00 & 1.00 \\
\hline
\end{tabular}

Source: Own preparation on the basis of the various executive reports on the global statistics for ISO 9000 published by ISO.

Note: Up to the year 2000 the certificates analysed are ISO 9001, ISO 9002 and ISO 9003; from 2001 onwards the certificate analysed is ISO 9001:2000. CI (certification Intensity) calculated as the ratio between the percentage share of the number of certificates issued worldwide and the percentage share of total world GDP in 2009 measured in US dollars at current exchange rates of the time (World Bank).

Within the EU-27 (see Table 3), with the CI calculated as being the ratio between the percentage share of the number of certificates issued in the EU and the percentage share of total GDP of the EU, of special note is the loss in intensity of the United Kingdom and the growth experienced by Italy and Spain - two leading countries as far as the implementation of MSSs is concerned. Specifically and in absolute terms, Italy is ranked second in the world behind China, in terms of the number of ISO 9000 certificates, and it is followed by Japan and Spain.

Regarding the transition economies of the EU, special mention should also be made of the performance of the countries that have most recently joined the Union (see Figure 2). In the end of 2009 all the transition economies had a CI bigger than 1. Bulgaria with a CI of 5.60 in 2009 and Romania with a score of 3.87 were on the top of the ranking together with Czech Republic (with a CI of 3.35).

In the period under consideration, an increase has been noted within the EU-15, albeit by a slight proportion: from 291,793 certificates in 2005 , this figure increased to 346,378 in 2009 . In contrast, the increase in number of certificates experienced by those countries that gained accession in 2004 and 2007 is spectacular: between 1997 and 2005, the number of certificates multiplied twelve-fold and thirty-fold respectively, whereas among the EU-15 it only multiplied two and a half-fold. 
Table 3. Evolution of ISO 9000 certification within the EU

\begin{tabular}{|c|c|c|c|c|c|c|}
\hline & \multirow{2}{*}{1997} & \multirow{2}{*}{2001} & \multirow{2}{*}{2005} & \multicolumn{3}{|c|}{2009} \\
\hline & & & & Numb. & $\%$ & $C I$ \\
\hline Austria & 2,627 & 4,000 & 3,368 & 4,277 & 1.05 & 0.49 \\
\hline Belgium & 3,042 & 4,670 & 4,810 & 3,950 & 0.97 & 0.36 \\
\hline Denmark & 1,902 & 2,163 & 1,219 & 1,683 & 0.41 & 0.22 \\
\hline Finland & 1,445 & 1,870 & 1,914 & 2,243 & 0.55 & 0.38 \\
\hline France & 11,920 & 20,919 & 21,700 & 23,065 & 5.66 & 0.37 \\
\hline Germany & 20,656 & 41,629 & 39,816 & 47,156 & 11.58 & 0.59 \\
\hline Greece & 682 & 2,325 & 3,255 & 5,034 & 1.24 & 0.68 \\
\hline Ireland & 2,534 & 3,700 & 2,055 & 2,136 & 0.52 & 0.34 \\
\hline Italy & 12,134 & 48,109 & 98,028 & 130,066 & 31.95 & 2.55 \\
\hline Luxembourg & 89 & 108 & 147 & 247 & 0.06 & 0.20 \\
\hline Netherlands & 10,380 & 12,745 & 9,160 & 12,260 & 3.01 & 0.66 \\
\hline Portugal & 819 & 2,474 & 8,520 & 5,051 & 1.24 & 0.94 \\
\hline Spain & 4,268 & 17,749 & 47,445 & 59,576 & 14.63 & 1.72 \\
\hline Sweden & 2,789 & 4,652 & 4,744 & 5,346 & 1.31 & 0.49 \\
\hline United Kingdom & 56,696 & 66,760 & 45,612 & 41,193 & 10.12 & 0.61 \\
\hline$E U-15$ & 131,983 & 233,873 & 291,793 & 343,283 & 84.31 & 0.91 \\
\hline Cyprus & 42 & 334 & 530 & 677 & 0.17 & 1.27 \\
\hline Czech Rep. & 746 & 5,627 & 12,743 & 14,031 & 3.45 & 3.35 \\
\hline Estonia & 1 & 202 & 489 & 746 & 0.18 & 1.47 \\
\hline Hungary & 1,341 & 6,362 & 15,464 & 7,122 & 1.75 & 2.14 \\
\hline Latvia & 1 & 67 & 561 & 708 & 0.17 & 1.06 \\
\hline Lithuania & 29 & 202 & 591 & 1,111 & 0.27 & 1.20 \\
\hline Malta & 45 & 207 & 302 & 420 & 0.10 & 2.29 \\
\hline Poland & 669 & 2,622 & 9,718 & 12,707 & 3.12 & 1.23 \\
\hline Slovakia & 404 & 827 & 2,050 & 3,475 & 0.85 & 1.94 \\
\hline Slovenia & 467 & 1,026 & 2,114 & 1,688 & 0.41 & 1.49 \\
\hline Joined in 2004 & 3,745 & 17,476 & 44,562 & 42,685 & 10.48 & 1.81 \\
\hline Bulgaria & 42 & 469 & 2,220 & 5,322 & 1.31 & 5.60 \\
\hline Romania & 214 & 1,670 & 6,097 & 15,865 & 3.90 & 3.87 \\
\hline Joined in 2007 & 256 & 2,139 & 8,317 & 21,187 & 5.20 & 4.19 \\
\hline$E U-27$ & 135,984 & 253,488 & 344,672 & 402,016 & 100 & 1 \\
\hline
\end{tabular}

Source: Own preparation on the basis of the various executive reports on the global statistics for ISO 9000 published by ISO.

Note: Up to the year 2000 the certificates analysed are ISO 9001, ISO 9002 and ISO 9003; from 2001 onwards the certificate analysed is ISO 9001:2000. CI calculated as the ratio between the percentage share of the number of certificates issued in the EU and the percentage share of total EU GDP in 2009 published by Eurostat. 


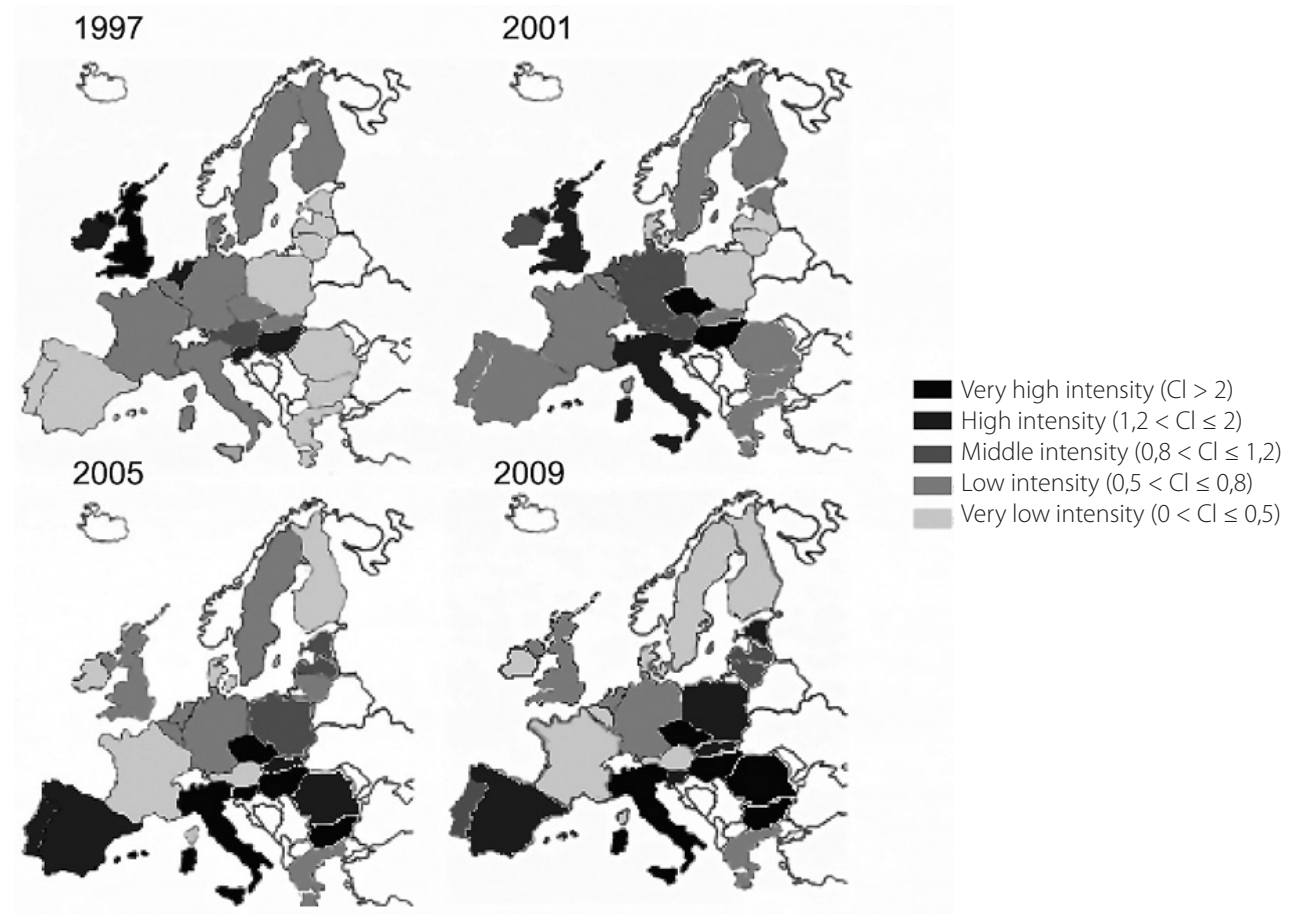

Fig. 2. Evolution of the Certification Intensity of ISO 9000 in the EU

Source: Own preparation on the basis of data obtained from ISO reports and from Eurostat. Note: Calculations made on the basis of GDP for 2004 measured in terms of PPP (purchasing power parity).

In relative terms, this fact makes things even clearer, if that is possible. In Figure 3 the evolution of the Certification Intensity of ISO 9000 is charted for the EU-15, for the countries that joined in 2004 the EU and for the ones that joined in 2007. It can be observed that while the Certification Intensity of ISO 9000 has stabilized for the EU-15, it has grown a lot both for the member states that joined the Union in 2004 and 2007 respectively.

Nevertheless, it can be observed that for the case of the member states that joined the Union in 2004, there has been an important reduction of the Certification Intensity after the year of adhesion. Indeed, in Cyprus, the Czech Republic, Hungary, Latvia, Slovenia and Poland, the total number of certificates decreased one year after joining the EU. Only Poland recovered the rate it reached in 2005 in 2008. Specifically, the ten countries that joined the EU in 2004 went on from being in possession of 44,562 certificates to 39,578 certificates in three years.

In contrast, those countries that gained accession in 2007 have not yet started to lose their weight. Romania and Bulgaria are maintaining a major increase in the number of certificates issued. Attention should be drawn to the fact that the number of certificates issued has increased in four years: they were in possession of 8,317 certificates in 2005, whereas this figure had increased to 21,187 by 2009 . It remains to be seen whether they 


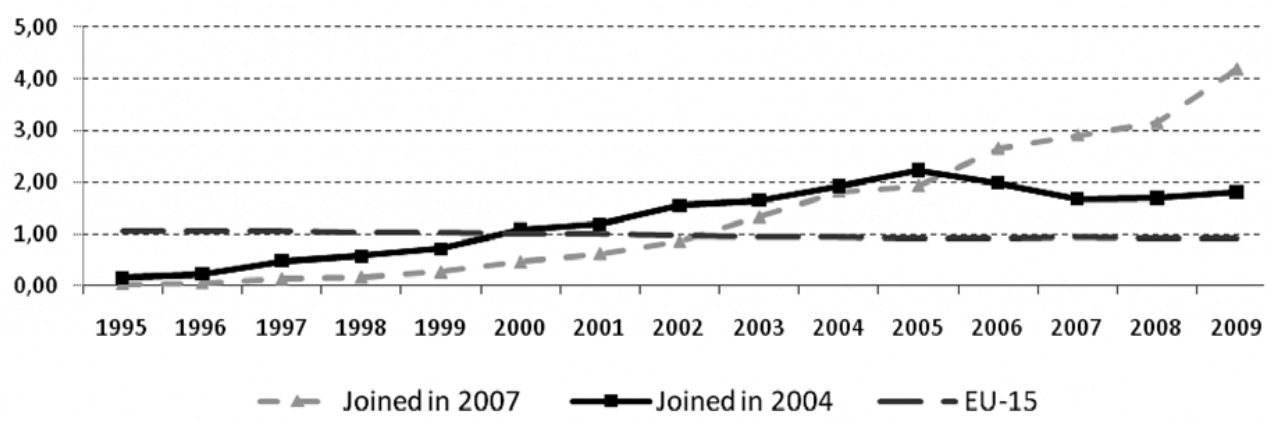

Fig. 3. Comparative evolution of the Certification Intensity of ISO 9000 in the EU Source: Own preparation on the basis of the various executive reports on the global statistics for ISO 9000 published by ISO

will manage to maintain this rate of increase or whether certification will start to lose force - as has taken place in those countries that gained accession in 2004.

Regarding the sectorial evolution of ISO 9000 within the transition economies (see Figure 4), if that sectorial evolution is analysed in terms of three broad basic divisions by sector - representing industry, construction and services - for the EU-15 we can clearly see the widespread growth in certification experienced in the service sectors, while at the same time there is an equally widespread reduction in certifications in the industrial field. The reduction of ISO 9000 certifications in the manufacturing sector has been also important for the countries that joined the Union in 2004, but it has been a really big one for Bulgaria and Romania.

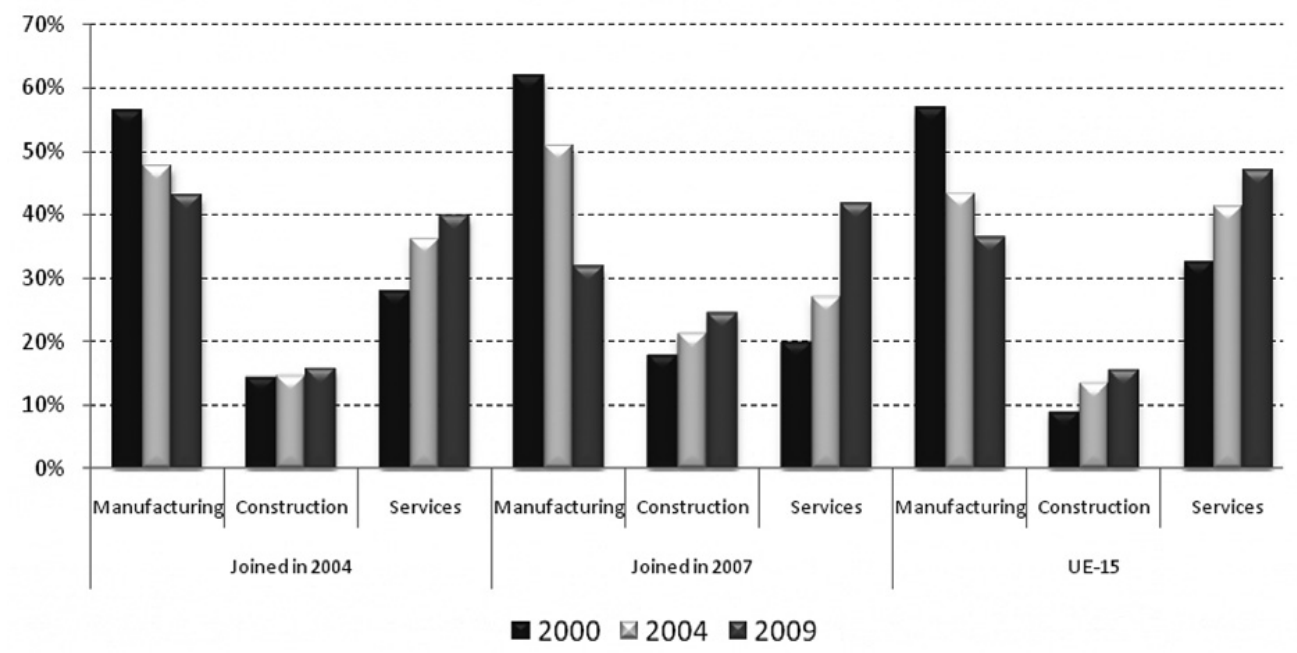

Fig. 4. Evolution of the sector distribution of ISO 9000 within the joined in 2004, joined in 2007 and EU-15

Source: Own preparation on the basis of ISO full reports of global statistics for ISO 9000 (ISO, 2000-2010). 


\section{Adoption of ISO 9000 in the Baltic States}

In the case of the Baltic States, it is observed that in ten years - from 1999 to 2009 there was a spectacular growth in the number of certificates from 207 in 1999 to 2,565 certificates in 2008. However, as can be seen in Figure 5, in the wake of major growth in 2004 and the slight subsequent increase in 2005 and 2006, there has since been a reduction in the number issued. The Baltic States saw a reduction in its number of certificates from 1,899 in 2006 to 1,776 in 2007, as a consecuence of the major reduction of the certificates from 625 to 342 in Latvia during this year.

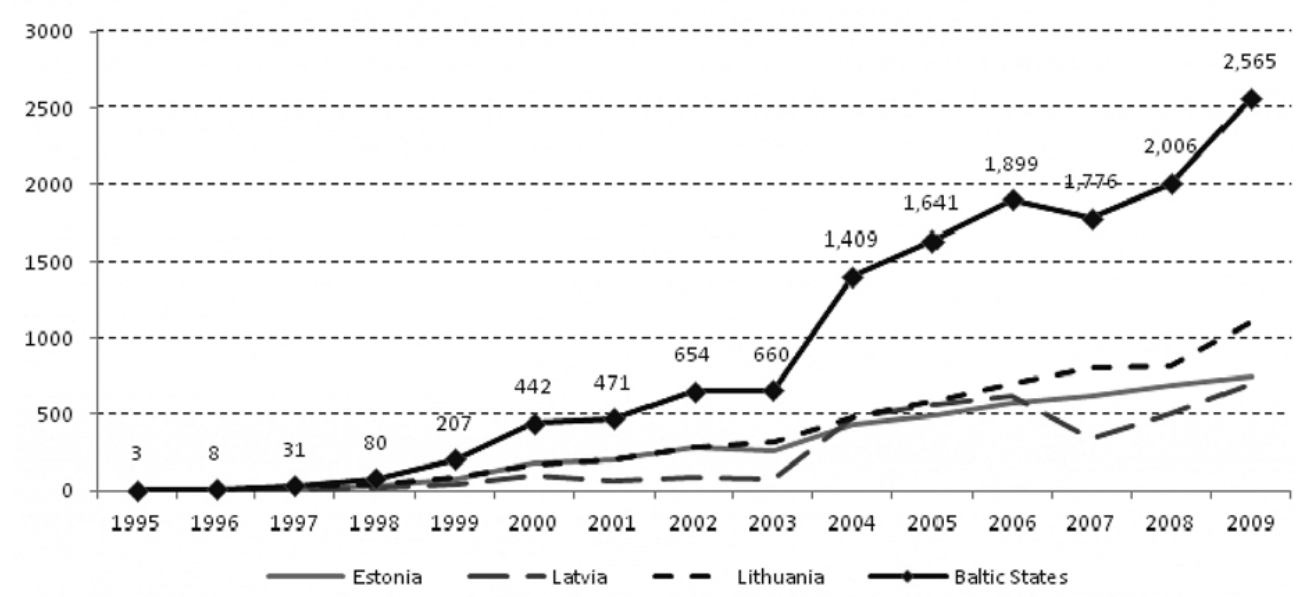

Fig. 5. Evolution of ISO 9000 certifications in the Baltic States

Source: Own preparation on the basis of ISO full reports of global statistics for ISO 9000

(ISO, 1998-2010).

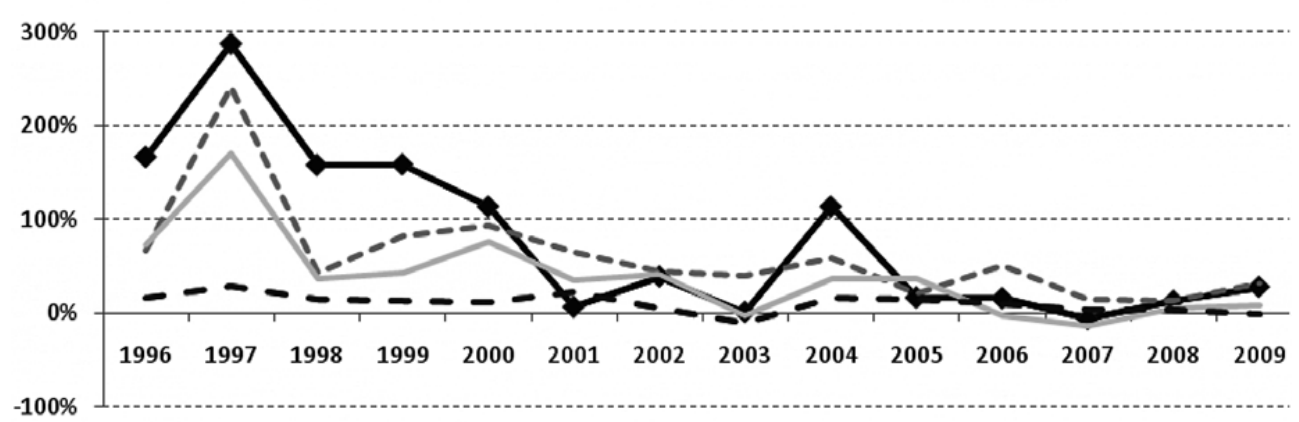

$\longrightarrow$ Baltic states - - - Joined in $2007 \quad$ Rest of joined in $2004 \quad-$ EU-15

Fig. 6. Comparative evolution of percentual growth of ISO 9000 certifications. (Baltic States, Rest of joined in 2004, joined in 2007 and EU-15)

Source: Own preparation on the basis of ISO full reports of global statistics for ISO 9000 (ISO, 1998-2010). 
If this evolution is compared to what has taken place in the other countries that joined the EU in 2004 (see Figure 6), it can be ascertained that the sharp increase in the number of certificates issued in the Baltic States occurred in 2004, and it is bigger than the percentual growth of the rest of countries joined in 2004 and 2007. Likewise, the decrease in number of certificates following accession to the EU followed a similar pattern following the level of stability reached in 2006. In the case of the EU-15, however, it can be noted that there has been a clear stabilization phase with an average growth rate of $8.3 \%$ over the period 1999-2009.

As far as detailed distribution of ISO 9000 certificates issued in the Baltic States according to sector is concerned, and as can be seen in Table 4, attention should be drawn to the weight of the construction (accounting for around 23\% of the total), basic metal and fabricated metal products sector $8.5 \%$ and other services $(7.5 \%)$. In contrast, special mention should be made of the no certification in hotels and restaurants $(0.0 \%)$.

If the evolution of distribution of ISO 9001 certificates in the Baltic States is analysed from its European perspective (taking into consideration as a reference those member states that gained accession to the EU in 2004 and the EU-15), it is observed (see Figure 7) that a reduction in the number of certificates has been experienced in the manufacturing sector - less than that of the EU-15 and of the other countries that joined the EU in 2004.

Looking to the future, it is difficult to estimate the evolution of the number of ISO certificates that are likely to be issued in the Baltic States. There are many economic and institutional factors which, as has been referred to in the analysis of literature available on the subject, may have a bearing on the process of development of such certificates. The major economic crisis which is currently being experienced on a global level may also have a marked influence on such evolution.

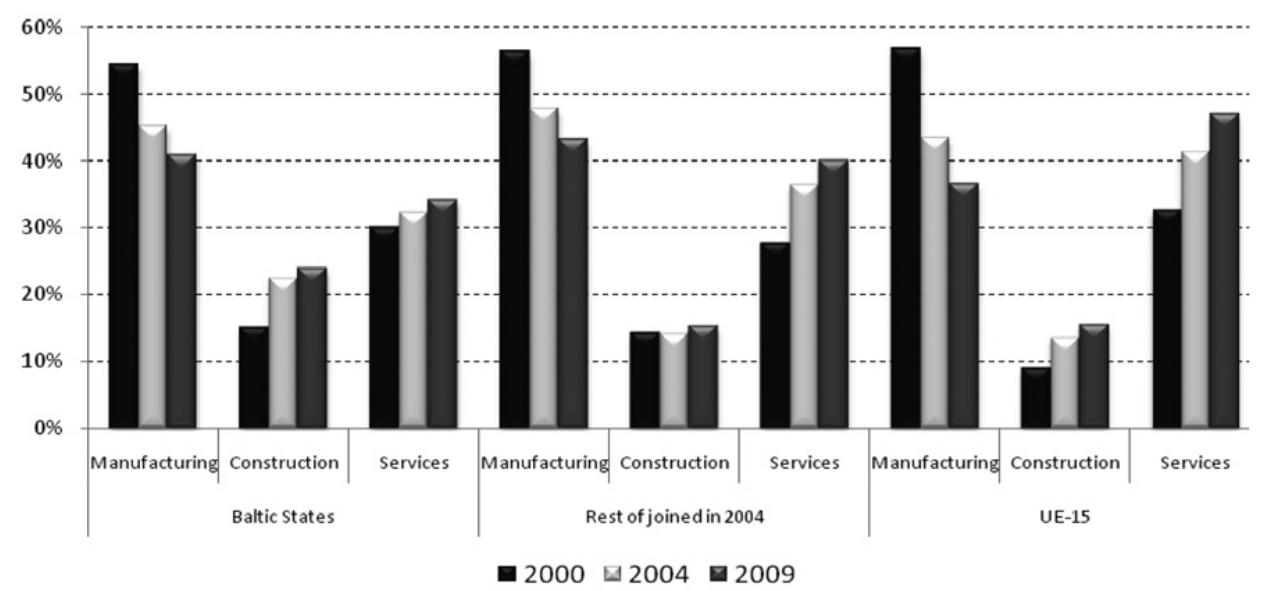

Fig. 7. Comparative distribution of ISO 9000 certificates in industry, construction and the services sector in the Baltic States, Rest of joined in 2004 and EU-15

Source: Own preparation on the basis of ISO full reports of global statistics for ISO 9000

(ISO 1999-2010). 
I. Heras-Saizarbitoria et al. Adoption of ISO 9000 management standard in EU's transition economies ...

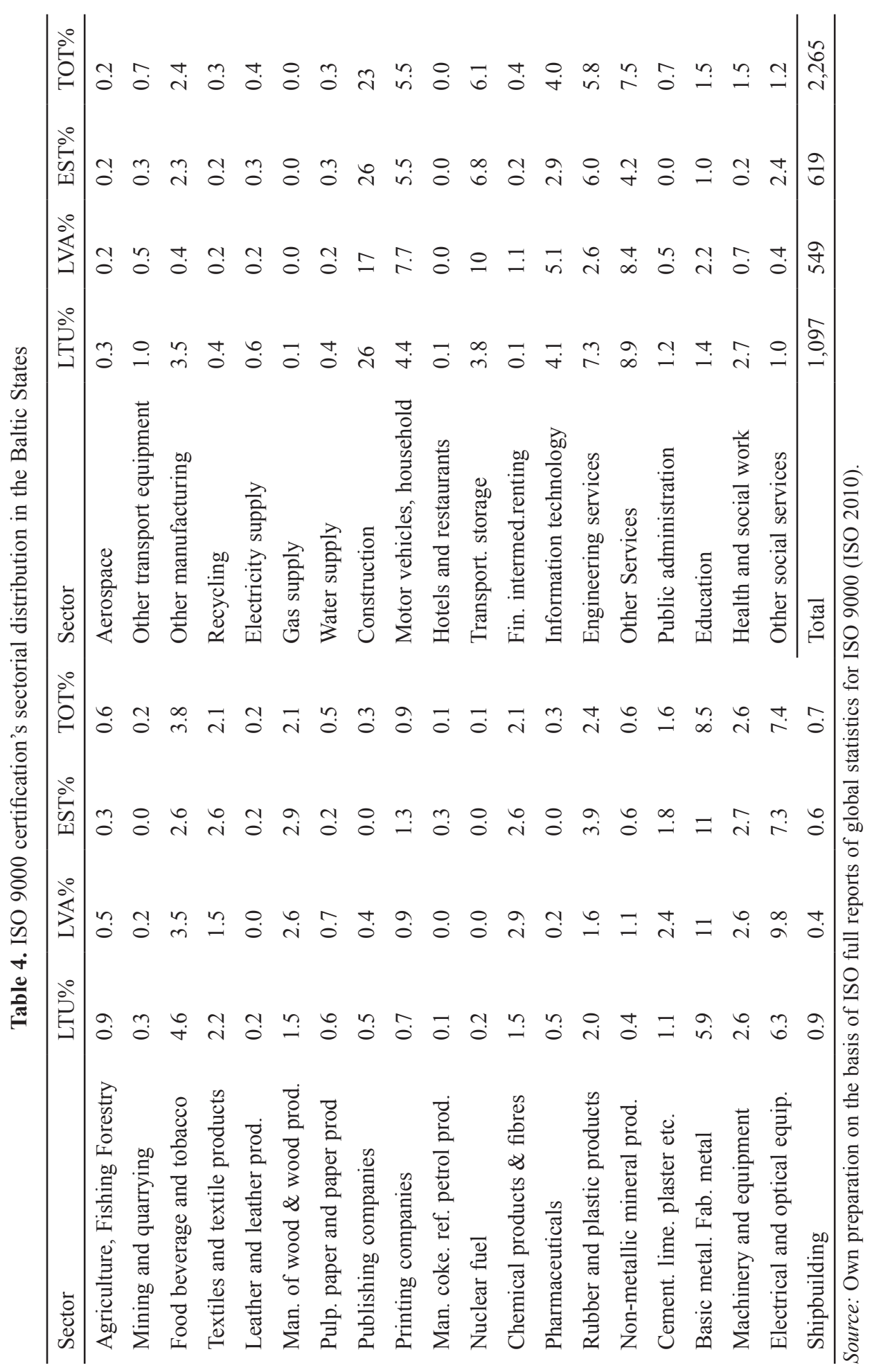




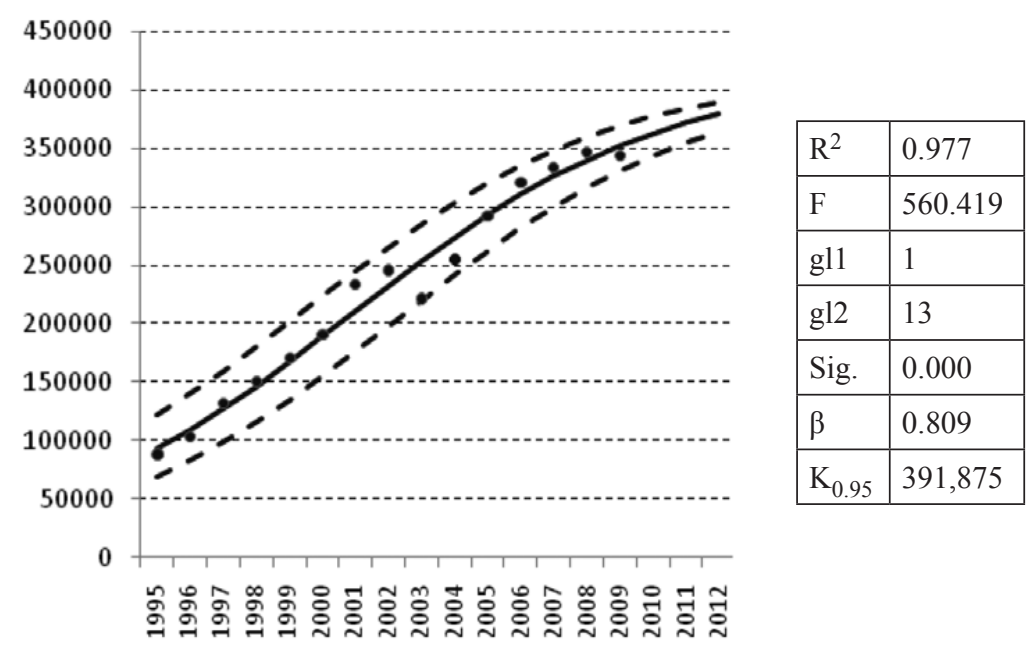

Fig. 8. Forecast of the ISO 9000 certificates in the EU-15

Source: Own preparation on the basis of ISO full reports of global statistics for ISO 9000 (ISO 1999-2010).

However, diverse research has attempted to propose methodologies to help make estimates as to the evolution of this type of MSS. Franceschini et al. (2004) and Marimón et al. (2006) have established that the logistic curve explains and forecasts the dissemination of ISO 9000 certification well.

For the EU-15 case, in Figure 8 it may be observed how the logistic model suits the current certification data, with a fit of $97.7 \%$ for R squared. At present, we are at $83.2 \%$ of the saturation level for the ISO 9000 . Considering $95 \%$ as a possible saturation point, the forecast according to this model is to arrive at a maximum of ISO 9000 certificates in 2014 .

In the specific case of the Baltic States, as shown in Figure 9, it can be observed that the logistic model suit it very well. The R Square value 0.98 it is fine, but it can be seen how in the five consecutive years from 1997 to 2002 the certificates existing in all cases were above the line of prediction levels for the model. This is because from 2003 to 2006 the number of new certificates has been increased a lot. According to this model, in 2009 it has reached the saturation point of this model.

If we analyse what has been taking place in the other countries that joined in 2004, it can be seen in Figure 10 that a similar phenomenon occurs. In both cases, major growth is noted in the years prior to 2006. In that year, things stagnated with slight growth in the case of the Baltic States and a slight drop in the case of the other countries that gained accession in 2004. After 2007, the number of certificates issued decreased markedly in both cases. In this case, the R Square of the model for the purpose of making the prediction was 0.91 while, however, the growth forecast for the years 2007 and 2008 at a saturation level in this case of $78 \%$ has not been able to be confirmed with real data. 


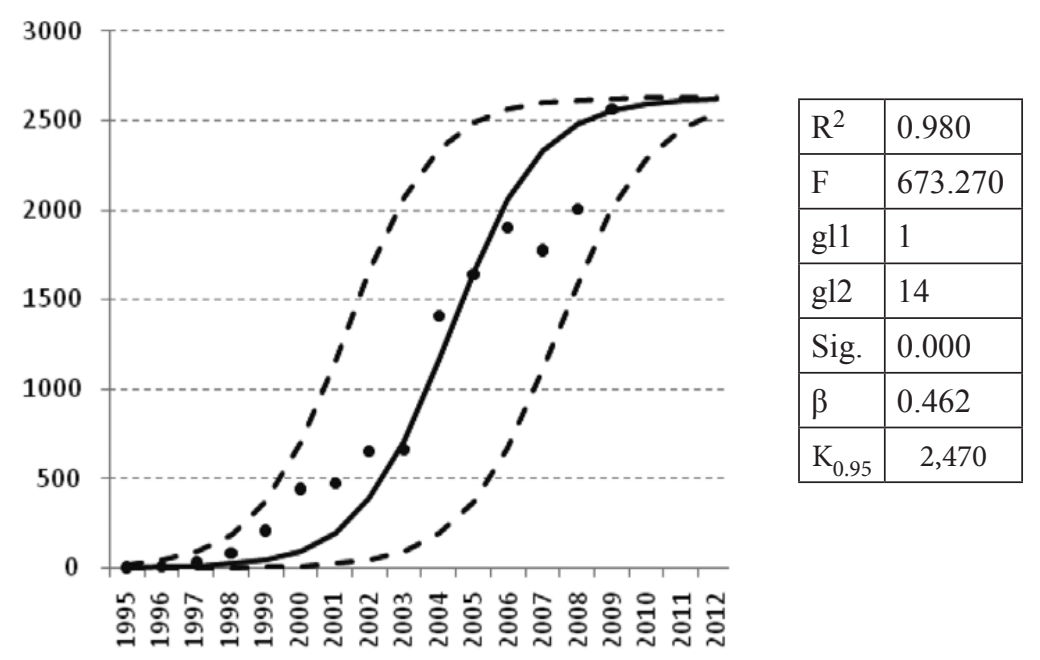

Fig. 9. Forecast of the ISO 9000 certificates in the Baltic States

Source: Own preparation on the basis of ISO full reports of global statistics for ISO 9000 (ISO 1999-2010).

However, for the countries joined in 2007, in Figure 11 it may be observed how the logistic model suits the current certification data, with a fit of $96.2 \%$ for R squared. At present, we are at $98,1 \%$ of the saturation level for the ISO 9000 , but if we analized the increment of the certificates during the last year, it looks like that the tendecy has changed, and the saturation point could get a bigger value in the following years.

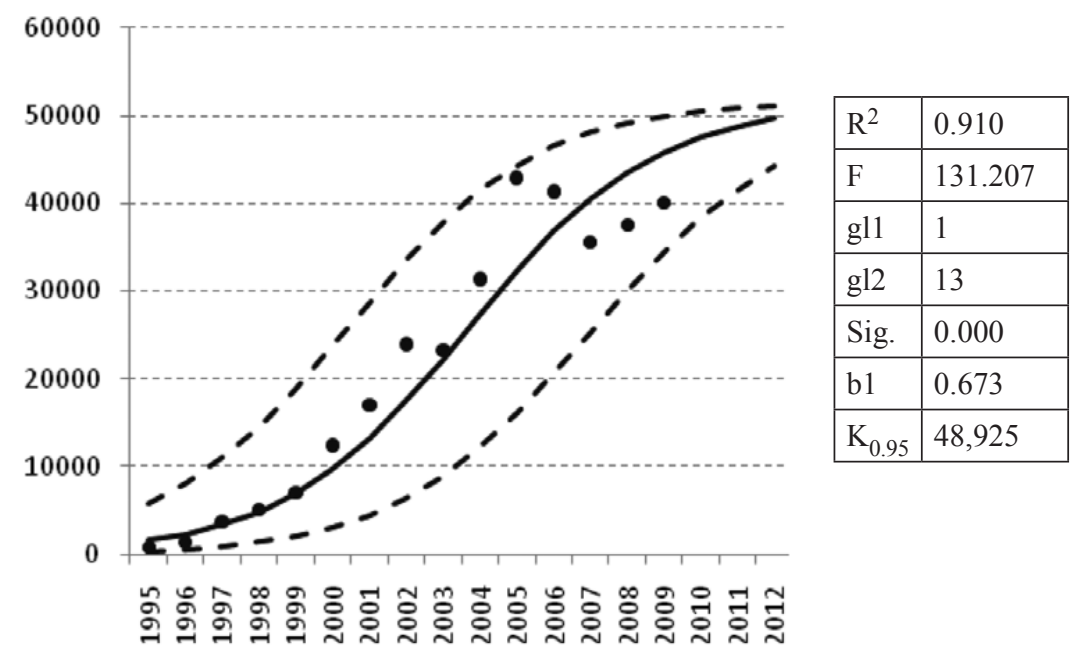

Fig. 10. Forecast of the ISO 9000 certificates in rest of the countries joined in 2004 Source: Own preparation on the basis of ISO full reports of global statistics for ISO 9000 (ISO 1999-2010). 


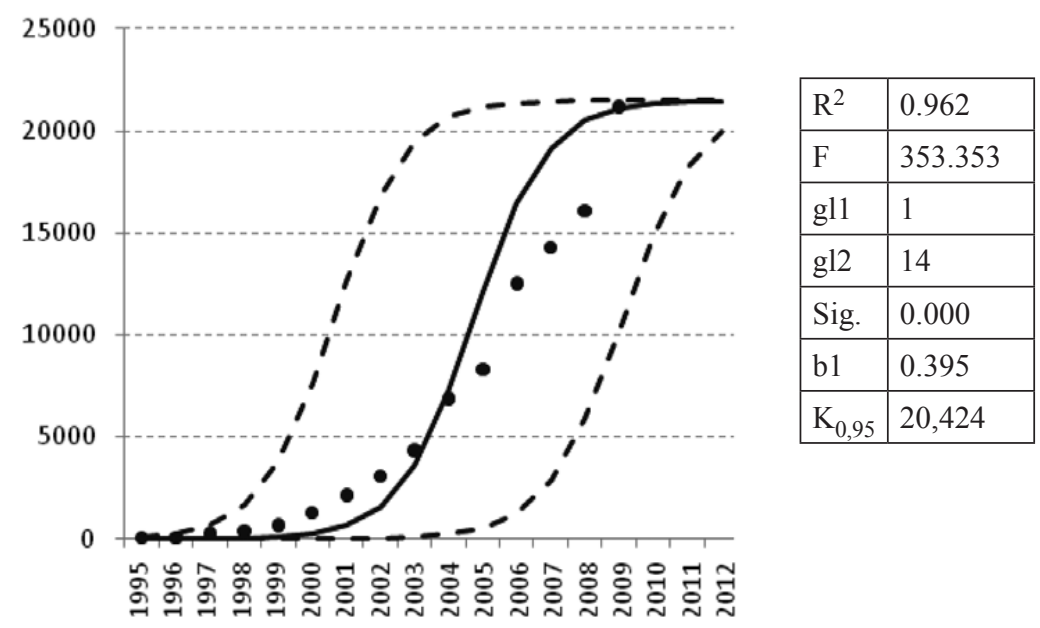

Fig. 11. Forecast of the ISO 9000 certificates in the countries joined in 2007 Source: Own preparation on the basis of ISO full reports of global statistics for ISO 9000 (ISO 1999-2010).

\section{Discussion and conclusions}

In the course of the work carried out, the major level of dissemination achieved by the EU's transition economies, in general, and the Baltic States, in particular, has been noted. More specifically, from 2003 to 2006 the number of new certificates has been increased a lot in the Baltic States, and, according to the model of diffusion, in 2009 it has been reached the saturation point.

In fact, the forecasting model would seem to evidence the fact that in the case of the Baltic States and that of the other countries with transition economies that gained access to the EU, the dissemination of certificates is close to reaching its maturity, albeit with levels of saturation that are significantly lower than those of the member states that make up the EU-15. Furthermore, the work refers to the huge increase of certifications achieved by the transition economies in the previous years of their adhesion to the European Union in years 2004 and 2007, and the reduction of the growth of certifications of the last years.

Nevertheless, it has to be pointed out that without a detailed analysis, it is difficult to know whether this sharp drop in the growth of certificates is due to endogenous circumstances related to the certification process itself that has started to be noted in some Western countries (Marimón et al. 2009), or to factors of an exogenous nature, such as those related to the economic crisis being currently experienced by Western economies.

As stressed in the work, several factors are analyzed in the academic literature as macro-drivers for the ISO 9000 adoption. These studies stress that there exists a positive correlation between the number of certificates and macro-economic variables such as 
the volume of direct overseas investment, the tendency to export to the EU and the country's public expenditure (see Table 1). Although many interesting results have been obtained, clear answers are still waiting to be found to such elementary questions as to what we can attribute the fact that some countries which are not present at the highest level in international indices of competitiveness (e.g., Italy, Spain and Israel) nevertheless have indices of certification in relation to their economic level that place them at the top of the global league table, whereas other countries that appear at the top of the competitiveness indices referred to even within the EU (e.g., Germany and Finland) have much lower indices of certification.

In the specific case of the transition economies, it would seem clear that the effort made to adapt and come into line with the EU has been a key factor. In fact, it has to be taken into account that in the beginning of the nineties, for instance, various administrations and European institutions, and specifically the European Commission, promoted intensively the adoption of this standard by European companies, as part of the process of harmonization that was established with a view to creating the single European market in 1992 (Tsiotras and Gotzamani 1996; Crowe et al. 1998), and that it was even included in the commercial directives of what was then the European Community (Anderson et al. 1999; Mendel 2002). Moreover, within the new menber states of the EU, this process would seem to have been, if possible, even clearer and more accelerated - owing to the pressure exerted by EU institutions and by local institutions themselves. National campaigns and subsidies (for the Baltic Case see, f.i. Ginevičius and Tvaronavičiene 2003, Tvaronavičiene and Ginevičius 2003; Tamošiūniene et al. 2007 to promote the adoption of ISO standards would seem to be among the factors that influence decisions regarding certification (Heras et al. 2008 claim this, for example, in the case of Spain). Nevertheless, this is a factor that has not been studied in-depth enough in literature on the subject.

In our opinion, in order to make progress with this line of research, importance should be given to approaches which gather specific evidence linked to the various different public and private programmes to promote metastandards that have been established in national contexts. As a result of all the above, experience in recent years of the transition economies in general, and the specific case of the Baltic States in particular, could prove to be a very interesting case study from this research perspective, both for academic and practitioner purposes, and, overall, for public decision-makers.

For managers and policy-makers in all over the European Union, but specifically within the so-called transition economies of the EU, this work has some interesting implications. One of them is related to the characteristics of the dissemination model proposed for ISO 9001 standard. In short, the possible loss of appeal of the adoption of ISO 9001 could be inferred from the model, since the intrinsic value of the certificate is not constant, but rather tends to decrease in an environment in which possessing the aforementioned certificate does not prove to be a distinguishing factor for companies. Needless to say that policy-makers in transition member states of the EU should take this issue into account in an environment of global economic crisis and deep transformations in the field of international business. 


\section{Acknowledgements}

This article is a result of a Research Group funded by the Basque Autonomous Government (Grupos de investigación del sistema universitario vasco; IT763-13). The authors wish to express their sincere thanks to the Editor of JBEM and to the reviewers for their assistance; their constructive criticisms and suggestions helped us to improve and develop the article substantively.

\section{References}

Alburquerque, P.; Bronnenberg, B. J.; Corbett, C. J. 2007. A spatiotemporal analysis of the global diffusion of ISO9000 and ISO14000 Certification, Management Science 53(3): 451-468. ISSN 0025-1909.

Anderson, S. W.; Daly, J. D.; Johnson, M. F. 1999. Why firms seek ISO 9000 certification: regulatory compliance or competitive advantage?, Production and Operations Management 8(1): 28-43. ISSN 1059-1478. http://dx.doi.org/10.1111/j.1937-5956.1999.tb00059.x

Antonelli, C. 1994. Localized technological change and the evolution of standards as economic institutions, Information Economics and Policy 6(3-4): 195-216. ISSN 0167-6245.

Blind, K. 2004. The Economics of Standards: Theory, Evidence, Policy. Massachussets: Edward Elgar Publishing. ISBN 1-84376-7937.

Bodas-Freitas, I. M. 2009. The diffusion of ISO 9000 and ISO 14001 certification, cross sectoral evidence from eight OECD countries, in DRUID Society Summer Conference 2009 on Innovation, Strategy and Knowledge, 17-19 June, 2009, Copenhagen Business School (CBS), Copenhagen, Denmark, 1-31.

Boiral, O. 2001. ISO 14001 certification in multinational firms: the paradoxes of integration, Global Focus 13(1): 79-94. ISSN 1525-0369.

Braun, B. 2005. Building global institutions: the diffusion of management standards in the world economy - an institutional perspective, in C. G. Alvstan, E. W. Schamp (Eds.). Linking Industries Across the World. London: Ashgate. ISBN 0-7546-4426-X.

Brunsson, N.; Jacobsson, B. 2000. The contemporary expansion of standardization, in N. Brunsson, B. Jacobsson (Eds.). A World of Standards. Oxford: Oxford University Press, 1-16. ISBN 0-19-829693-2.

Cao, X.; Prakash, A. 2007. Growing exports by signaling product quality: trade competition and the cross-national diffusion of ISO 9000 quality standards, Journal of Policy Analysis and Management 26(3): 527-555. ISSN 1520-6688.

Clougherty, J.; Grajek, M. 2008. The impact of ISO 9000 diffusion on trade and FDI: a new institutional analysis, Journal of International Business Studies 39(4): 613-633. ISSN 0047-2506. http://dx.doi.org/10.1057/palgrave.jibs.8400368

Cole, R. E. 1999. Managing quality fads: how American business learned to play the quality game. Oxford university press. ISBN 0-19-512260-7.

Corbett, C. J. 2008. Global diffusion of ISO 9000 certification through supply chains, Supply Chain Analysis International Series In Operations Research and Management 119: 169-199. ISSN 0884-8289

Corbett, C. J.; Yeung, A. C. L. 2008. Special issue on meta-standards in operations management: cross-disciplinary perspectives, International Journal of Production Economics 113(1): 1-2. ISSN 0925-5273. http://dx.doi.org/10.1016/j.ijpe.2007.02.044

Corbett, C. J.; Kirsch, D. A. 2001. International diffusion of ISO 14000 certification. Production and Operations Management 10(3): 327-342. ISSN 1059-1478.

http://dx.doi.org/10.1111/j.1937-5956.2001.tb00378.x 
Crowe, T. J.; Noble, J. S.; Machinada, J. S. 1998. Multiattribute analysis of ISO 9000 registration using AHP, International Journal of Quality and Reliability Management 15(2-3): 205-222. ISSN 0265-671X. http://dx.doi.org/10.1108/02656719810368495

Dick, G. 2000. ISO 9000 certification benefits, reality or myth?, The TQM Magazine 12(1): 365-371. ISSN 0954-478X. http://dx.doi.org/10.1108/09544780010351517

Duanmu, J. L.; Fai, F. M. 2007. A processual analysis of knowledge transfer: from foreign MNEs to Chinese suppliers, International Business Review 16(4): 449-473. ISSN 0969-5931. http://dx.doi.org/10.1016/j.ibusrev.2007.04.004

Franceschini, F.; Galetto, M.; Gianni, G. 2004. A new forecasting model for the diffusion of ISO 9000 standard certifications in European countries, International Journal of Quality and Reliability Management 21(1): 32-50. ISSN 0265-671X. http://dx.doi.org/10.1108/02656710410511687

Furusten, S. 2000. The knowledge base of standards, in N. Brunsson, B. Jacobsson (Eds.). A World of Standards. Oxford: Oxford University Press, 71-74. ISBN 0-19-829693-2.

Ginevičius, R.; Tvaronavičiene, M. 2003. Globalization processes in Baltic countries: analysis of trends in Lithuania, Latvia and Estonia, Journal of Business Economics and Management 4(1): $62-71$.

Grajek, M. 2004. Diffusion of ISO 9000 Standards and International Trade, CIG Working Papers SP II 2004-16, Wissenschaftszentrum Berlin (WZB), Research Unit: Competition and Innovation (CIG). ISSN 0722-6748.

Guasch, J. L.; Racine, J. L.; Sánchez, I.; Diop, M. 2007. Quality Systems and Standards for a Competitive Edge. The World Bank. ISBN 0-8213-6895-8. http://dx.doi.org/10.1596/978-0-82136894-7

Guler, I.; Guillen, M. F.; Macpherson, J. M. 2002. Global competition, institutions, and the diffusion of organizational practices: The international spread of ISO 9000 quality certificates, $\mathrm{Ad}$ ministrative Science Quarterly 47: 207-232. ISSN 0001-8392. http://dx.doi.org/10.2307/3094804

Heras, I. 2006. Génesis y auge de los estándares de gestión: una propuesta para su análisis desde el ámbito académico, in I. Heras (Ed.). ISO 9000, ISO 14001 y otros estándares de gestión: pasado, presente y futuro, Madrid: Cívitas, 25-58. ISBN 9788447026869.

Heras, I.; Arana, G.; Díaz de Junguitu, A.; Espí, M.; Molina, J. F. 2008. Los Sistemas de Gestión Medioambiental y la competitividad de las empresas de la Comunidad Autónoma del País Vasco. San Sebastián, Fundación Deusto. ISBN 9788498301793.

ISO. 2010. The ISO survey of ISO 9000 and ISO 14000 certifications. Geneva, ISO. ISBN 97892-67-10535-2.

Liuhto, K.; Jumpponen, J. 2003. The internationalization process of the largest Baltic corporations, Journal of Business Economics and Management 4(1): 21-23.

Marimón, F.; Casadesús, M.; Heras, I. 2006. ISO 9000 and ISO 14000 standards: an international diffusion model, International Journal of Operations and Production Management 26(2): 141-165. ISSN 1059-1478. http://dx.doi.org/10.1108/01443570610641648

Marimón, F.; Casadesús, M.; Heras, I. 2009. ISO 9000 and ISO 14000 standards: a projection model for the decline phase, Total Quality Management and Business Excellence 20(1): 1-21. ISSN 1478-3363. http://dx.doi.org/10.1080/14783360802614257

Masakure, O.; Henson, S.; Crandfield, J. 2009. Standards and export performance in developing countries: evidence from Pakistan, Journal of International Trade and Economic Development 18(3): 396-397. ISSN 0963-8199. http://dx.doi.org/10.1080/09638190902986538

Mendel, P. J. 2002. International standardization and global governance: the spread of quality and environmental management standards, in A. J. Hoffman, M. J. Ventresca (Eds.). Organizations, Policy and the Natural Environment: Institutional and Strategic Perspectives. Stanford University Press, 407-424. ISBN 9780804741958. 
Nadvi, K.; Waltring, F. 2004. Making sense of global standards, in H. Schmitz (Ed.). Local Enterprises in the Global Economy: Issues of Governance and Upgrading. Massachussets: Edward Elgar Publishing. ISBN 1-84376-099-1.

Neumayer, E.; Perkins, R. 2005. Uneven geographies of organizational practice: explaining the cross-national transfer and adoption of ISO 9000, Economic Geography 81(3): 237-259. ISSN 1468-2702. http://dx.doi.org/10.1111/j.1944-8287.2005.tb00269.x

Pan, J. 2003. A comparative study on motivation for and experience with ISO 9000 and ISO 14000 certification among far Eastern countries, Industrial Management and Data Systems 103(8-9): 564-578. ISSN 0263-5577. http://dx.doi.org/10.1108/02635570310497611

Seddon, J. 1997. Pursuit of Quality: the Case Against ISO 9000. Dublin: Oak Tree Press. ISBN 1860760422.

Shin, S. 2005. The role of the government in voluntary environmental protection schemes: the case of ISO 14001 in China, Issues and Studies 41(4): 141-173. ISSN 1013-2511.

Tamošiūniene, R.; Šidlauskas, S.; Trumpaite, I. 2007. EU structural support and its impact on Lithuania's progress, Journal of Business Economics and Management 8(3): 177-187.

Tapiero, C. S. 2006. Strategic quality assurance, Journal of Business Economics and Management 7(1): 29-35.

Tsiotras, G.; Gotzamani, K. 1996. ISO 9000 as an entry key to TQM: the case of Greek industry, International Journal of Quality and Reliability Management 13(4): 64-76. ISSN 0265-671X. http://dx.doi.org/10.1108/02656719610114407

Tvaronavičiene, M.; Ginevičius, R. 2003. Analysis of foreign direct investments and its' impact on restructuring of Lithuanian economy, Journal of Business Economics and Management 4(3): 184-197.

Uzumeri, M. 1997. ISO 9000 y other metastandards: principles for management practice?, Academy of Management Executive 11(1): 21-36. ISSN 0896-3789.

Iñaki HERAS-SAIZARBITORIA. Dr, is an Associated Professor at the Department of Business Management at the University College of Business Studies of San Sebastian of the University of Basque Country, in Spain. He studied business economics at the University of Basque Country. Likewise, he studied at the ESST master's program (production systems, innovations, and development models) in Roskilde University (Denmark). He has published several articles in both national and international academic journals, such as European Business Review, Journal of Management Research and Total Quality Management. He has also participated as a main researcher in several projects on ISO 9000 financed by The Basque Country University and the Spanish Administration.

Germán ARANA. Dr, is an Associated Professor at the Department of Business Management at the Polytechnical College of San Sebastian of the University of Basque Country, in Spain. He studied Business Engineering at the University of Navarra. His doctoral thesis is about the effects on business performance of TQM models. He has published several articles in both national and international academic journals, such as International Journal of Quality \& Reliability Management, International Journal of Operations and Production Management and European Business Review. He has also participated as a researcher in several projects on the adoption of TQM financed by the Spanish Administration.

Ernesto CILLERUELO. Dr, is a Full Professor at the Department of Business Management at the he Engineering School of Bilbao of the University of Basque Country, in Spain. He studied Business Engineering at the University of Basque Country. He has published several articles in both national and international academic journals, such as Managing Service Quality, International Journal of Health Care Quality Assurance and Leadership in Health Services. Due to his practitioner expertise, he has participated as a main researcher in several projects financed by Spanish companies. Likewise, he has coordinated more than 20 projects related to the adoption of ISO 9000 and other models for Quality Management in both public and private organizations. 